\title{
Study on Micropropagation of Coleus Blumei Benth. through Apical Meristem Culture
}

\author{
Mariani TS ${ }^{1 *}$, Siregar AS $^{1}$ and Hiroshi Miyake ${ }^{3}$ \\ ${ }^{1}$ Bandung Institute of Technology, Indonesia \\ ${ }^{2}$ Nagoya University, Japan
}

Submission: March 12, 2019; Published: April 10, 2019

"Corresponding author: Mariani TS, Biosciences and Biotechnology Research Center, Bandung Institute of Technology, Ganesha 10, Bandung 40132, Indonesia

\begin{abstract}
Coleus blumei Benth is an economically important plant. As a medicinal plant, C. blumei has been used for the treatment of heart disease, insomnia, skin problem. In this study, micropropagation of $C$. blumei has been performed through meristem culture. Shoots derived from meristem culture were obtained on MS medium supplemented with $0.5 \mathrm{mg} / \mathrm{l} \mathrm{BAP}$ and $0.025 \mathrm{mg} / \mathrm{l} \mathrm{NAA}$. The shoots grew after one month of culture. Then roots developed after one month of culture forming plantlets. After acclimatization for two months, the plant grew well and the whole leaves show purple color.
\end{abstract}

Keywords: Coleus blumei; Meristem culture; Plantlet; Plant

\section{Introduction}

Ornamental plant, Coleus blumei Benth., which belongs to the family Lamiaceae, is a natural hybrid of several Coleus species. It has attractive foliage and, therefore, it is planted extensively as a decorative indoor and outdoor plant [1].

Economically, the member of the genus Coleus is of great importance acting as source of medicines, providing food and as ornamentals. Different species of Coleus has been used for the treatment of variety of diseases including heart disease, abdominal colic, respiratory disorders, insomnia, skin problem [2].

Micropropagation of Coleus have been performed on several explants, namely nodal segment, shoot tip [1], binodal mini-top grafting cutting [3] and leaf [4]. In this study, we carried out meristem culture of Coleus for micropropagation.

It is necessary to propagate the Coleus because of their advantages. According to Mariani et al. [5] meristem culture has benefits as follow:

a) The plants will be pathogen free because donor plant does not contain vascular bundle. Vascular bundle can carry the pathogen.

b) The plants will be genetically stable because meristem is a differentiated tissue.

c) The plants will not be callusing. Therefore, it will reduce somaclonal variation. d) The purpose of this study was to propagate the Coleus blumei in order to pathogen free, genetically stable and reduce somaclonal variation.

\section{Material and Methods}

\section{Mersitem culture and multiplication}

a) The explant (shoot) was surface sterilized by $96 \%$ alcohol for 30 second and $20 \%$ chlorox for 3 minutes. Then, the explants were washed by sterile water 4 times.

b) The scale of the shoot was opened under stereomicroscopy until $0.2-0.5 \mathrm{~mm}$ shoot mersitem was obtained.

c) The shoot meristem was cultured on initiation media MS containing $1 \mathrm{gl}$ active charcoal for 2 weeks.

d) Thereafter, the shoot was subcultures on MS media supplemented with $0.5 \mathrm{mg} / \mathrm{l}$ BAP and $0.025 \mathrm{mg} / \mathrm{l} \mathrm{NAA}$ for multiplication.

\section{Acclimatization}

a) After plantlet developing, the plants were acclimatized by covering them with plastic bag. The plastic bag could be opened after 1 month.

b) The plant was fertilized by Grow More in order to growing healthy and well. 


\section{Results and Discussion}

Shoots and root of Coleus blumei derived from meristem culture is shown in Figure 1 The shoots were growing on MS media supplemented with $0.5 \mathrm{mg} / \mathrm{l} \mathrm{BAP}$ and $0.025 \mathrm{mg} / \mathrm{l} \mathrm{NAA}$ for multiplication. By using $0.025 \mathrm{mg} / \mathrm{l} \mathrm{NAA}$, root could develop in the same medium. Smith et al. [6] reported that at least $0.1 \mathrm{mg} / \mathrm{l}$ IAA and optimally $1-2 \mathrm{mg} / \mathrm{l}$ IAA were required for development into

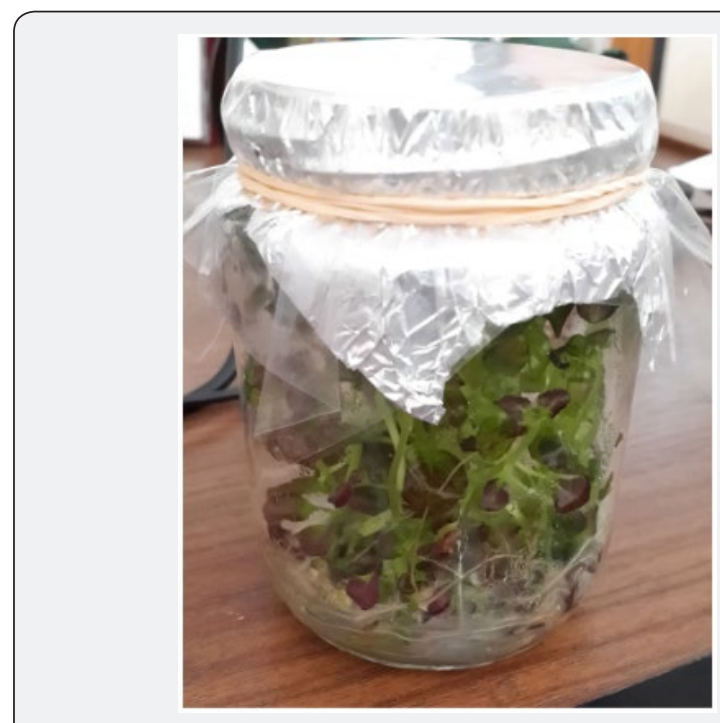

Figure 1: Plantlet of Coleus blumei.

Meristem development into a plant first involved formation of leaf primordia. Establishment of a bipolar axis with root formation followed [6]. This study supported their research. We observed shoot formation and root formation followed (Figure 1). After acclimatization for 1 month, the plant could grow and showing a little bit purple color. The plant grew well and the whole leaves show purple colors after 2 months (Figure 2).

\section{References}

1. Rani G, Tolwan D, Nagud A, Virk GS (2006) Micropropagation of Coleus blumei from nodal segments and shoot tips. Biologia plantarum 50(4): 496-500.

2. Nagpal A, Singh B, Sharma S, Rani G, Virk GS (2008) Coleus spp: Micropropagation and in vitro production of secondary metabolites. Medicinal and Aromatic Plant Science and Biotechnology. Global Science Books. complete plants. In this study we used NAA in lower concentration. It is $0.025 \mathrm{mg} / \mathrm{l} \mathrm{NAA}$.

Different species of Coleus, namely Coleus forskohlii, has been reported by Atulkar et al. [7]. They used apical shoot and auxiliary meristem as the explants. They also mentioned that auxiliary meristem explants were more pronounced effect of shoot induction rather than apical shoot.

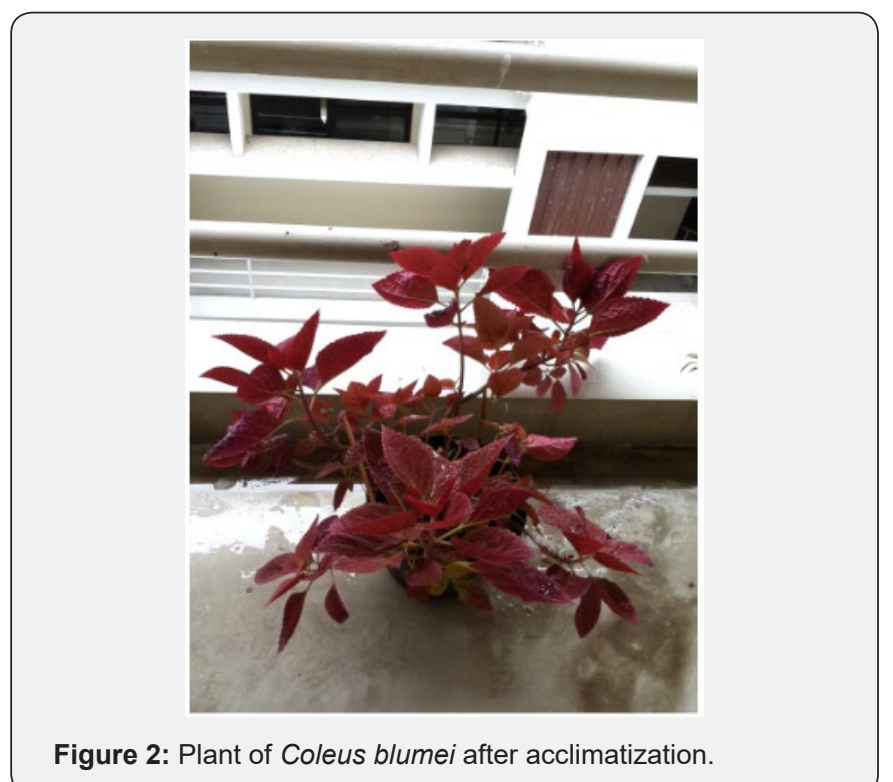

3. Vasile L, Ioana VS, Zapartan M, Agud E (2011) In vitro micropropagation of Coleus blumei Benth species. Analele universititatii din Oradea Protectia Mediului XVII: 253-258

4. Jing W, Ye C, Rongmei L, Baozhorg H (2008) Study on the tissue culture of Coleus blumei. Journal of Northeast Agricultural University 15(1): 14-17.

5. Mariani TS, Siregar AS (2015) Meristem culture of Aloe vera Linn and its acclimatization. Asian Journal of Applied Sciences 3(2): 286-289.

6. Smith RH, Murashige T (1982) Primordial leaf and phytohormone effects on excised shoot apical meristems of Coleus blumei. Amer Botany 69(8): 1334-1339.

7. Atulkar P, Thakur R, Singh P, Khan S (2013) Effect of different growth regulator on in vitro shoot induction of Coleus forskohlii Briq from apical shoots and auxiliary meristems-A valuable medicinal herb of high commercial value. International Journal of Indigenous Medicinal Plants 46(2): 1305-1309. 
This work is licensed under Creative

Commons Attribution 4.0 License

DOI: 10.19080/JOJHA.2018.01.555588
- Quality Editorial service

- Swift Peer Review

- Reprints availability

- E-prints Service

- Manuscript Podcast for convenient understanding

- Global attainment for your research

- Manuscript accessibility in different formats ( Pdf, E-pub, Full Text, Audio)

- Unceasing customer service

Track the below URL for one-step submission https://juniperpublishers.com/online-submission.php 